\title{
ADH1C Gene
}

National Cancer Institute

\section{Source}

National Cancer Institute. ADH1C Gene. NCI Thesaurus. Code C111822.

This gene is involved in the metabolism of alcohols. 